\title{
The first data on the infestation of the parti-coloured bat, Vespertilio murinus (Chiroptera, Vespertilionidae), with gamasid mites, Steatonyssus spinosus (Mesostigmata, Gamasina, Macronyssidae)
}

\author{
Maria V. Orlova, Denis V. Kazakov, Oleg L. Orlov, Vladimir A. Mishchenko \\ \& Alexandr V. Zhigalin
}

\begin{abstract}
This article presents one of the very few records of a macronyssid mite (Mesostigmata, Gamasina, Macronyssidae) infestation of vesper bats (Chiroptera, Vespertilionidae). It is the first report of the influence of host parameters on the infestation of the parti-coloured bat, Vespertilio murinus, by the mite Steatonyssus spinosus. It has been shown that the infestation varies considerably throughout the host's occupation of summer roosts and the highest infestation was observed in the post-lactation period. Female bats are infested significantly more intensively than male bats due to changes in their immune status during pregnancy and lactation. The infestation decreases in the period when the breeding colony disbands due to both roost switching and the intensification of grooming during this period.

How to cite this article: Orlova M.V., Kazakov D.V., Orlov O.L., Mishchenko V.A., Zhigalin A.V. 2017. The first data on the infestation of the parti-coloured bat, Vespertilio murinus (Chiroptera, Vespertilionidae), with gamasid mites, Steatonyssus spinosus (Mesostigmata, Gamasina, Macronyssidae) // Russian J. Theriol. Vol.16. No.1. P.66-73. doi: 10.15298/rusjtheriol.16.1.06
\end{abstract}

KEY WORDS: Steatonyssus spinosus, gamasid mites, bat ectoparasites, parti-coloured bat.

MariaV. Orlova [masha orlova@mail.ru] National Research Tomsk State University, av. Lenina 36, Tomsk, 634050, Russia; Tyumen State University, Volodarskogo str., 6, Tyumen, 625003, Russia; Denis V. Kazakov [kazakov.denis.95@mail.ru] Irkutsk State University, Karl Marks str. 1, Irkutsk, 664003, Russia; Oleg L. Orlov [o_l_orlov@mail.ru] Ural State Pedagogical University, av. Kosmonavtov, 26, Ekaterinburg, 620017, Russia; Vladimir A. Mishchenko [innamoramento23@yandex.ru] Ural Federal University, Mira str., 19, Ekaterinburg, 620002, Russia; Alexandr V. Zhigalin [alex-zhigalin@mail.ru] National Research Tomsk State University, av. Lenina 36, Tomsk, 634050, Russia

\section{Первые данные по зараженности двухцветного кожана Vespertilio murinus (Chiroptera, Vespertilionidae) гамазовыми клещами Steatonyssus spinosus (Mesostigmata, Gamasina, Macronyssidae)}

\author{
М.В. Орлова, Д.В. Казаков, О.Л. Орлов, В.А. Мищенко, А.В. Жигалин
}

\begin{abstract}
РЕЗЮМЕ. Статья представляет одно из немногих исследований зараженности гладконосых летучих мышей (Chiroptera, Vespertilionidae) клещами-макрониссидами (Mesostigmata, Gamasina, Macronyssidae), и первое, посвященное влиянию физиологического состояния хозяев — двухцветных кожанов Vespertilio murinus на их зараженность гамазовыми клещами Steatonyssus spinosus. Установлено, что зараженность двухцветного кожана паразитами данного вида существенно меняется на протяжении пребывания хозяев в летних убежищах. Наиболее высока она в постлактационный период. Самки летучих мышей заражены значимо интенсивнее самцов, что обусловлено изменениями иммунного статуса в период беременности и лактации. В период распада выводковой колонии зараженность резко падает, что связано как со сменой убежищ в этот период, так и с усилившимся грумингом животных.
\end{abstract}

КЛЮЧЕВЫЕ СЛОВА: Steatonyssus spinosus, гамазовые клещи, эктопаразиты рукокрылых, двухцветный кожан.

\section{Introduction}

The study of the ecology of the parti-coloured bat, Vespertilio murinus Linnaeus, 1758 (Chiroptera, Vespertilionidae), is of big theoretical and practical significance due to insufficient knowledge and a high prevalence of this species in the temperate zone of the Old World.
The parti-coloured bat is a Palearctic species occurring over an extensive geographic area. It is widely distributed from the Asiatic Pacific coast through Siberia to eastern, northern and central Europe in the west. This species can be found in both urban, mountainous and agricultural areas. It roosts in crevices of buildings and trees during the summer; during winter, crevices in buildings are preferred to underground sites (Rydell \& 
Baagøe, 1994). Vespertilio murinus is known to migrate long distances of up to 2000 kilometers. As a result this species has been recorded in the Middle East (Turkey, Iran) (Benda \& Horáček 1998, Benda et al. 2012).

The ectoparasite fauna of $V$. murinus is of particular interest due to the frequent use of buildings and other human constructions as roosts by breeding colonies. Although no data are available on the medical significance of the macronyssid mites (Gamasina, Macronyssidae) associated with bats, many species belonging to this family whose hosts are rodents (Ornithonyssus bacoti (Hirst, 1913), O. bursa (Berlese, 1888), O. sylviarum (G. Canestrini et Fanzago, 1877) and others) are involved in the transmission of dangerous natural focal infections such as lymphocytic choriomeningitis, rickettsial pox, Q-fever, and tularemia (Zemskaya, 1973).

Despite some contradictory data, it is assumed that parasites can negatively affect host fitness (Marshall, 1981; Booth et al., 1993; Giorgi et al., 2001; Roulin et al., 2003; Lourenco \& Palmeirim, 2008). Meanwhile, information about the infestation of parti-coloured bats (both the species composition and quantitative characteristics) is thus far very scarce. It was previously reported that the most common ectoparasite of $V$. murinus is the gamasid mite Steatonyssus spinosus Willmann, 1936 (Mesostigmata, Gamasina, Macronyssidae), which is recorded throughout almost the entire range of this bat species (Till \& Evans, 1964; Pinchuk, 1971; Dusbabek, 1972; Ogajanyan \& Arutyunyan, 1974; Haitlinger, 1978; Micherdzinski, 1980; Teng, 1980; Rybin, 1983; Stanyukovich, 1990; Rupp et al., 2004; Orlova, 2013; Orlova et al., 2016).

Macronyssid species belonging to the subfamily Ornithonyssinae (ectoparasites with prolonged feeding according to Balashov (2009)) occupy an intermediate position between permanent and temporary parasites, but mites of the genus Steatonyssus are characterized by a high degree of adherence to the host (Stanyukovich, 1993) and quite pronounced host specificity (Orlova, 2013), with some species having become permanent parasites (Zemskaya, 1973). Ectoparasites belonging to the genus Steatonyssus parasitize hosts during their stay in the summer roosts (mainly, attics and tree holes). In autumn the bats with a few parasites migrate to hibernating roosts in Central Asia (Khabilov, 1992).

Permanent parasites and parasites with prolonged feeding are widely considered to be good models for understanding host-parasite relationships, primarily due to the effects of some host parameters (e.g., sex, age, body condition, and immunity status) at infestation (Encarnaçao et al., 2012). Most studies have been carried out on spinturnicid mites (Gamasina, Spinturnicidae) (Christe et al., 2000, 2003, 2007; Giorgi et al., 2001; Zahn \& Rupp, 2004; Luèan, 2006; Sharifi et al., 2008; Encarnaçao et al., 2012) and bat flies (Diptera, Nycteribiidae), with a few similar studies of macronyssid species in the temperate zone (Orlova et al., 2012; Orlova et al., 2015b) and tropical zone (Zhang et al., 2010).
In this study, we investigated the sex- and agespecific host-parasite relationships between the particoloured bat and its ectoparasitic mite $S$. spinosus. This is the first study of the quantitative aspects of $V$. murinus infestation with its most common ectoparasite and is the first study focused on the host preference of Steatonyssus associated with bats. Below we consider several factors, the impacts of which, in our opinion, might produce the infestation dynamics of the particoloured bat. We excluded from the discussion such factors as the size of the colonies and type of roost because the study was carried out on individuals from the same type of shelters and colonies of approximately the same size (see Materials and methods).

\section{Host physiology (sex, body condition)}

Although the literature suggests that the males are more susceptible to parasitic infestations than the females (Klein, 2000; Morales-Montor et al., 2004), for many groups of bat ectoparasites (Spinturnicidae, Macronissidae, and Nycteribiidae) a clear preference of host females has been described (Christe et al., 2000; Dick \& Patterson, 2006; Orlova et al., 2012; Sundari et al., 2012; Orlova et al., 2015a, b). This is reasonable because haematophagous ectoparasites actively choose hosts with low immunocompetence. It has repeatedly been shown that progesterone (a hormone contributing to pregnancy) suppresses the production of antibodies, and therefore is able to induce a greater susceptibility in pregnant females to various parasitic infestations (Furukawa et al., 1984; Toder et al., 1984; Baley \& Schacter, 1985; Miller \& Hunt, 1996; Savita \& Rai, 1998; McKay \& Cidlowski, 1999). Sex hormones can suppress immunocompetence and result in a higher infestation of females during pregnancy (Christe et al., 2000; Klein, 2004) and lactation (Lučan, 2006; Lourenço \& Palmeirim, 2008). In males, testosterone functions as an immunosuppressant (Grossman, 1985) and testosterone levels increase during spermatogenesis (Hosken \& O'Shea, 2001; Encarnação et al., 2012), which in boreal bat species is observed in September and October (this period was not available to us for monitoring).

\section{Host behavior}

Antiparasite host behaviour includes the selection of a partner for mating, avoidance of infested groups of relatives, clean nests and grooming (Hart, 1997). The last is one of the most effective ways to reduce the host infestation (Clayton, 1991; Mooring \& Hart, 1995; Hart, 1997; Wikel, 1999). For the representatives of different groups of vertebrates it has been shown that the increase in parasitic load leads to an increase in the intensity of grooming (Clayton, 1991; Mooring \& Hart, 1995; Giorgi et al., 2001). However, a significant disadvantage of this strategy is the increased energy cost (Møller et al., 1994). Female bats can reduce their 


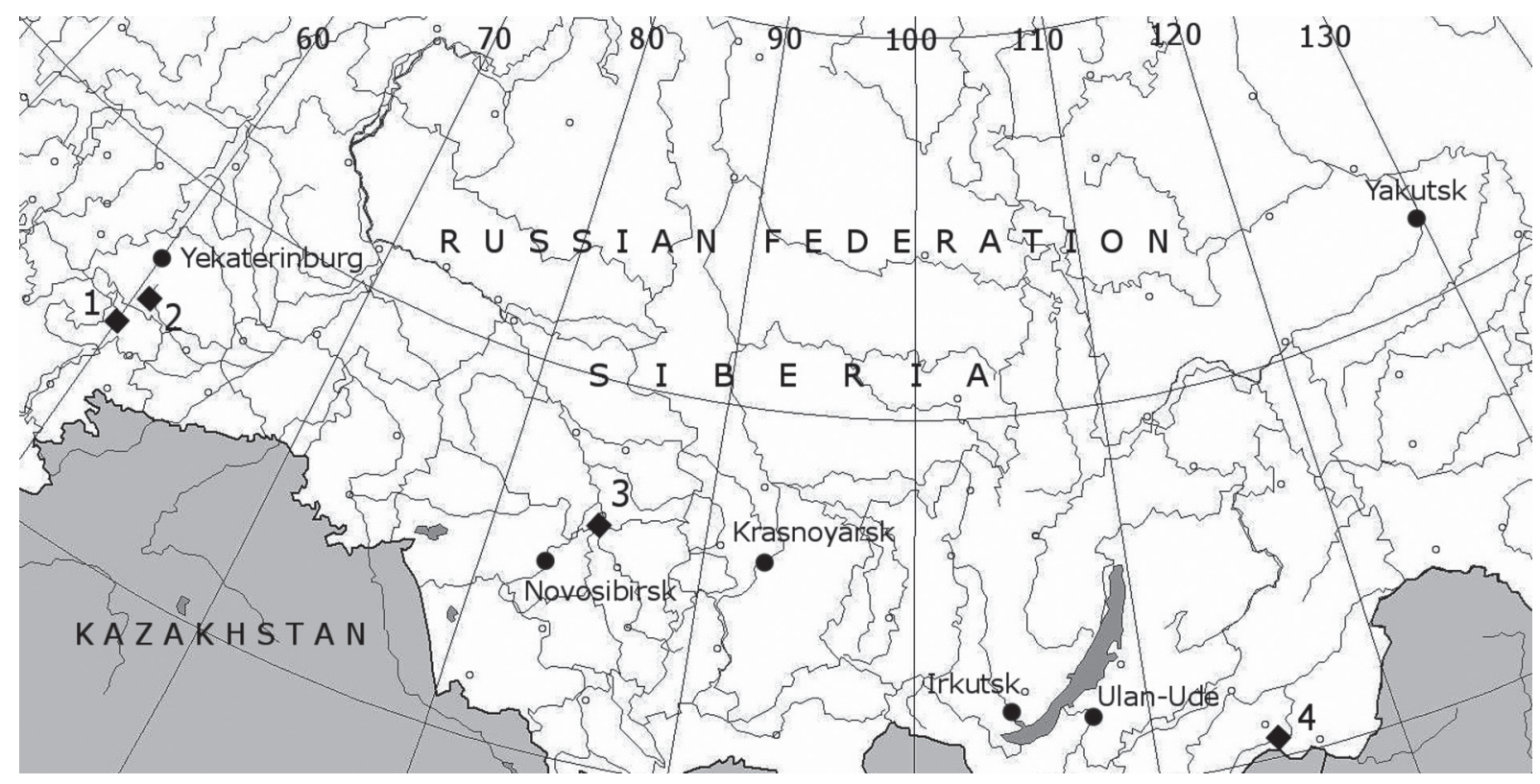

Fig. 1. Map of the collection points of parti-coloured bats in the Urals and Siberia. Notes: 1 - Chelyabinskaya Region, Kyshtym town; 2 - Sverdlovskaya Region, Yekaterinburg; 3 - Tomskaya Region, Tomsk; 4 - Zabaikal'skiy Territory, State biosphere natural reserve "Daursky".

grooming behaviour by up to $50 \%$ during lactation in the authors' opinion, to compensate for the increased energy demand (McLean \& Speakman, 1997) — while newborn pups are not able to receive effective grooming (McLean \& Speakman, 1997; Christe et al., 2000). However, adult males might not be restricted in their grooming behaviour throughout the entire activity period, since they do not experience an energy bottleneck comparable to that of the females during reproduction (Kurta et al., 1989, 1990).

Therefore, we can hypothesize that mite infestation in females (in our investigation most of them were reproductive) and juveniles is higher than in males, at least during the lactation/post-lactation period.

\section{Materials and methods}

The study was conducted from May 2014 until autumn 2016 (during the entire period of the bat's presence in the boreal zone) in specially selected and approximately same-sized (40-50 individuals) summer colonies of parti-coloured bats (mixed colonies containing individuals of both sexes) in the Urals and Siberia (Fig. 1). Breeding time in bats from all studied localities is highly synchronized, therefore collected material has been combined to conduct the analysis. All colonies were situated in anthropogenic shelters (mostly attics and other constructions). Bats were caught using both mist-nets and mobile traps (Borisenko, 1999). The age of bats, adult or juvenile, was identified by the presence or absence of the growth zones in metacarpals. Body mass (balance: Pesola, LightLine, accuracy $0.5 \mathrm{~g}$ ) and forearm length (dial calliper: Meazy, accuracy $0.1 \mathrm{~mm}$ ) were measured to calculate the body condi- tion index (BCI) (Vasen'kov \& Potapov, 2007). Adult females were classified as non-breeding, pregnant, lactating, or post-lactating (Racey, 2009).

Ectoparasites were removed with a preparatory needle and forceps and fixed in 70\% ethanol. Mites were mounted on permanent slides with Faure-Berlese's mounting medium (Whitaker, 1988). Ectoparasites were identified using light microscopy with an identification key (Stanyukovich, 1997). A total of $162 \mathrm{~V}$. murinus individuals were studied, from which 1648 ectoparasite specimens were collected. Mite infestation was characterized by the indexes $\mathrm{P}$ (prevalence), calculated as the percentage of infested individuals, and MI (mean intensity), calculated as the mean number of parasites per infested animal. Bats with no mites were also included in the analysis. After study, all animals were released in dwelling places.

The roosting of the bats in summer shelters was subdivided onto four periods according to reproductive state of bat population under the study: 1. pre-lactation (until June 20); 2. lactation (until July 15); 3. postlactation (until July 25); and 4. disbanding of the summer colony (until August 15). Pregnancy was estimated through a gentle palpation of the abdomen. Lactating females were identified according to enlarged nipples and fur absence in the nipple surroundings.

The factors potentially influencing ectoparasitic abundance were assessed using a general linear model (GLM). Mean abundance values are reported as the mean number of ectoparasites \pm standard error (SE) with an indication of the confidence interval (95\% CI).

GLMs were constructed by fitting the explanatory variable: fixed factors (period, host age, sex) and covariates (the body condition index), which could poten- 
Table 1. Results of GLM analysis (the first model) for the parasite infestation in bats as a function of period (pre-lactation, lactation, post-lactation and disbanding of the summer colony), body condition index (BCI) and sex (male, female) (only adult individuals). Significant differences are marked with an asterisk: ${ }^{*} \mathrm{p}<0.05$.

\begin{tabular}{|l|c|c|c|}
\hline & df & F & $\mathrm{p}$ \\
\hline Period & 3 & 9.61 & $<0.0001^{*}$ \\
\hline Sex & 1 & 8.46 & $0.01^{*}$ \\
\hline BCI & 1 & 0.07 & 0.79 \\
\hline Period $\times$ Sex & 3 & 5.73 & $0.001^{*}$ \\
\hline Period $\times$ BCI & 3 & 2.05 & 0.11 \\
\hline Sex $\times$ BCI & 1 & 1.82 & 0.18 \\
\hline Period $\times$ Sex $\times$ BCI & 3 & 1.19 & 0.32 \\
\hline Error & 73 & & \\
\hline
\end{tabular}

tially influence ectoparasite abundance. The significance level used was $\mathrm{p}<0.05$.

The impact of the studied factors on the infestation by ectoparasites was estimated by ANOVA for multiple factors and analysis of covariance (Faraway, 2006; Mastitskiy \& Shitikov, 2015). The statistical analysis was performed using R software, version 3.1.2 (R Foundation for Statistical Computing, packages 'car' and 'multcomp') (R Development Core Team, 2011; Shitikov \& Rosenberg, 2014). A posteriori (post hoc) multiple comparisons were performed using Tukey's HSD test.

\section{Results}

In the available observation period from May to September, all age and sex groups of the investigated animals were infested with $S$. spinosus. The first model $\left(\mathrm{R}^{2}=0.4 ; \mathrm{RSS}=17.78\right)$ (Table 1$)$ shows that adult females are infected significantly more than adult males $(p=0.01)(d f=1)$, and infestation varies significantly according to the period $(\mathrm{p}<0.0001)(\mathrm{df}=3)$; body condition has no effect on infection rates $(p=0.79)$. Infestation varied by period and showed the following dynamics: it increased in females during the pre-lactation $(\mathrm{MI}=2.8)$ and lactation (6.3) periods and peaked at post-lactation (32), followed by a sharp decline in infestation, and by the time the summer colony disbanded the MI had decreased to 1.3 (Figs. 2-4). The mite prevalence in females also decreased sharply from $75-82 \%$ in the pre-lactation/post-lactation period to $15 \%$ by the disbanding period. The pups were observed only during the lactation, post-lactation and disbanding periods. In the second model $\left(\mathrm{df}=1 ; \mathrm{R}^{2}=0.27\right.$; $\mathrm{RSS}=$ 34.27) (Table 2), age has no effect on infection rates ( $p$ $=0.06)$. The parasite load in juveniles demonstrated female-similar dynamics, with a sharp increase in infestation by the time the juveniles began to fly $(\mathrm{MI}=16.2$, $\mathrm{P}=91 \%)$ and a subsequent decrease $(\mathrm{MI}=8, \mathrm{P}=25 \%)$ (Figs 2, 4).

Infestation in males remained almost unchanged throughout the period of observation (Figs 2-4).

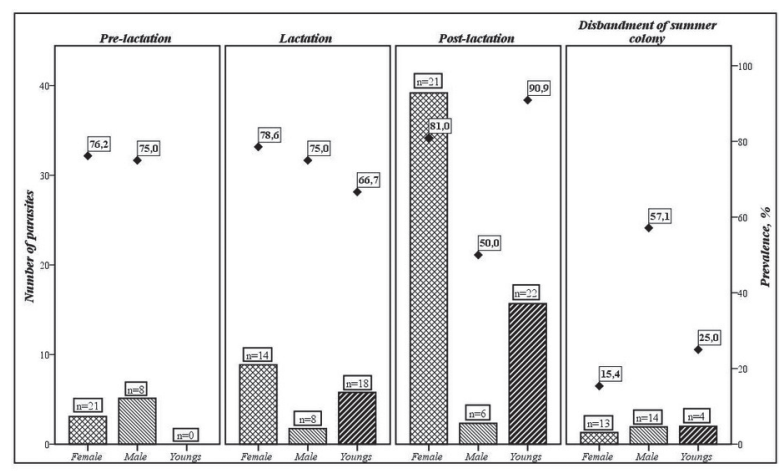

Fig. 2. Prevalence (\%, black diamonds) and mean intensity (columns) of adult males/females and juveniles. Numbers above the columns indicate the total sample size.

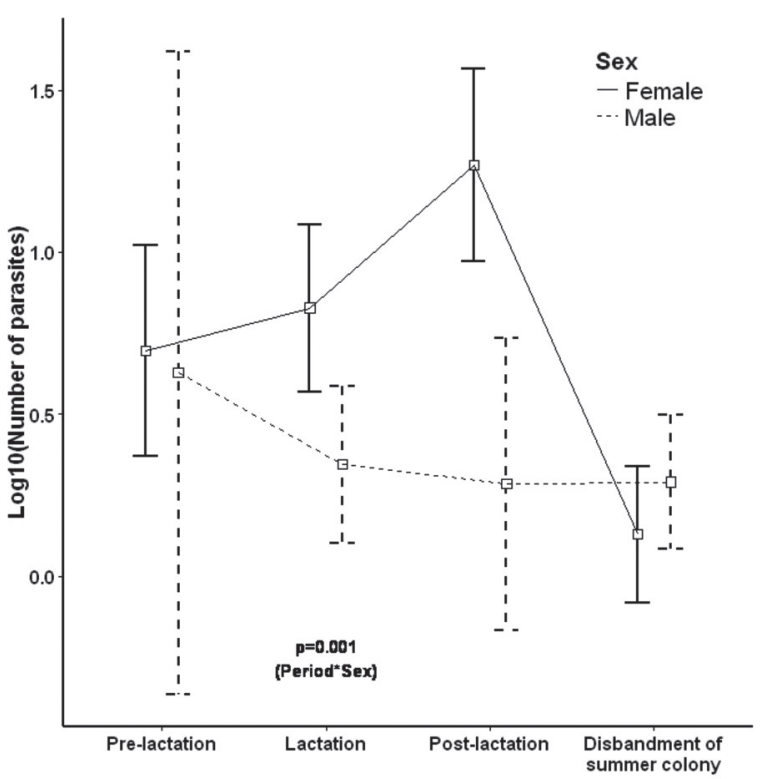

Fig. 3. Seasonal variation of the sex-specific parasite load in parti-coloured bats (adult specimens only) with mites (Steatonyssus spinosus). 

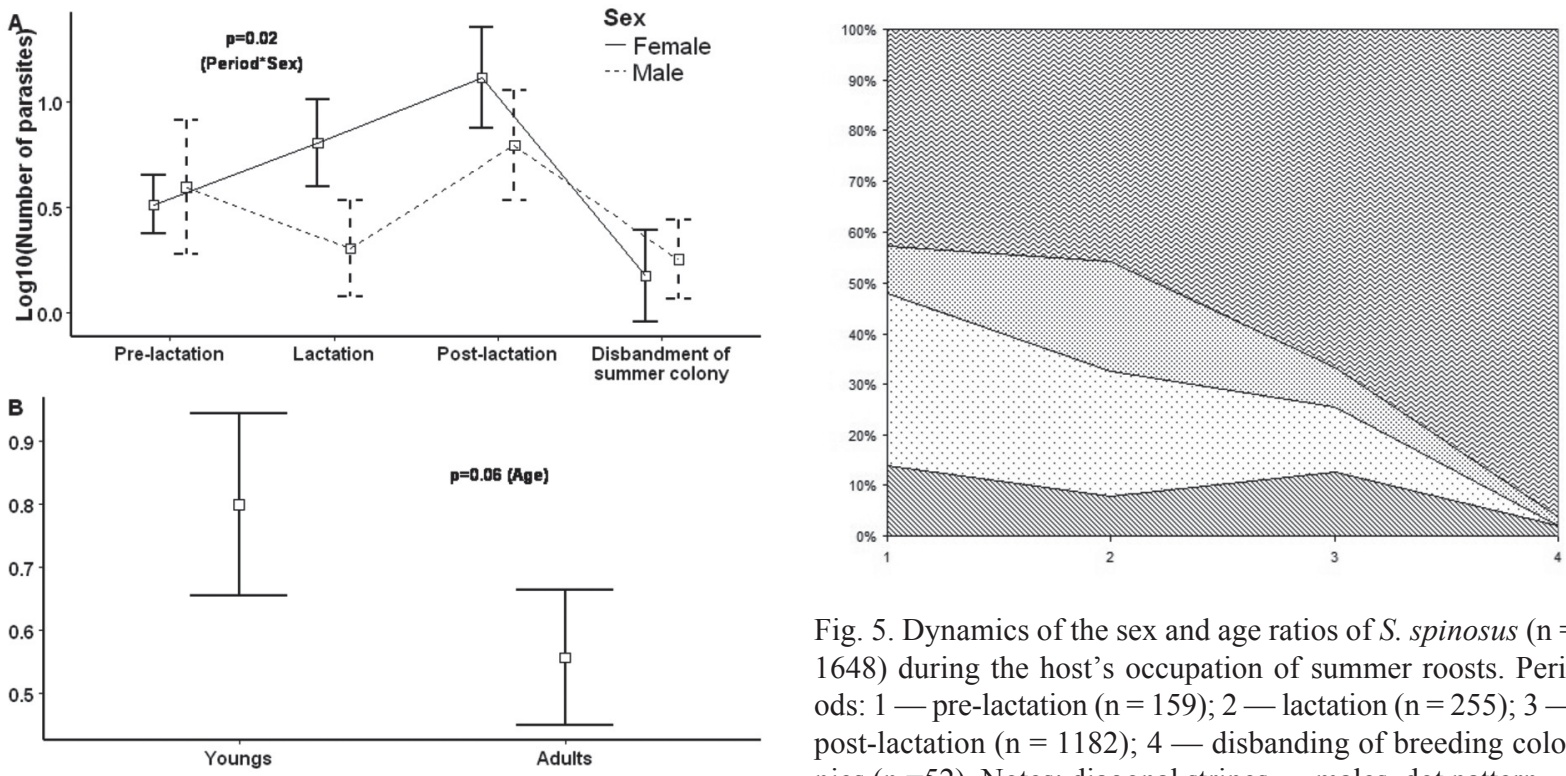

Fig. 5. Dynamics of the sex and age ratios of S. spinosus $(\mathrm{n}=$ 1648 ) during the host's occupation of summer roosts. Periods: 1 - pre-lactation $(\mathrm{n}=159) ; 2$ - lactation $(\mathrm{n}=255) ; 3$ post-lactation $(\mathrm{n}=1182)$; 4 - disbanding of breeding colonies $(\mathrm{n}=52)$. Notes: diagonal stripes — males, dot pattern females without intrauterine protonymphs, a frequent dot

Fig. 4. Seasonal variation of the sex- (juveniles included) (A) and age-specific (B) parasite loads in parti-coloured bats with mites (Steatonyssus spinosus). pattern - female with intrauterine protonymphs, waves protonymphs.

Table 2. Results of GLM analysis (the second model) for the parasite infestation in bats as a function of period (pre-lactation, lactation, post-lactation and disbanding of the summer colony), sex (male, female), and age (juvenile, adult). Significant differences are marked with an asterisk: ${ }^{*} \mathrm{p}<0.05$.

\begin{tabular}{|l|c|c|c|}
\hline & df & F & $\mathrm{p}$ \\
\hline Period & 3 & 13.71 & $<0.0001^{*}$ \\
\hline Sex & 1 & 5.46 & $0.02^{*}$ \\
\hline Age & 1 & 3.66 & 0.06 \\
\hline Period $\times$ Sex & 3 & 4.23 & $0.01^{*}$ \\
\hline Period $\times$ Age & 3 & 1.18 & 0.32 \\
\hline Sex $\times$ Age & 1 & 1.06 & 0.3 \\
\hline Period $\times$ Sex $\times$ Age & 3 & 2.08 & 0.11 \\
\hline Error & 143 & & \\
\hline
\end{tabular}

In the dynamics of the age and sex structure (Fig. 5) of $S$. spinosus, a high proportion of females with intrauterine eggs ( $47 \%$ of females, $21 \%$ of the total) occurs during host lactation. In the next period a reduction in the proportion of females with intrauterine eggs (up to $8 \%$ of the total) is synchronized with a rise in the proportion of protonymphs (from $45 \%$ in the lactation period to $67 \%$ in the post-lactation period). Obviously, the most intense reproduction phase in S. spinosus is synchronized with the periods of host pregnancy and lactation, and the result of this reproductive activity is reflected in the increased proportion of protonymphs, and eventually in the increased infestation of female bats during the post-lactation period.

\section{Discussion}

In this study, we analysed for the first time the hostparasite relationship of the parti-coloured bat and the gamasid mite $S$. spinosus throughout the entire period that $V$. murinus occupied summer shelters. Statistically significant sex differences in the infestation rate and its dynamics expressed by periods confirm earlier proposals.

It is remarkable that high infestations and their dynamics are observed only in females and juveniles. Enhanced mite reproduction (shown by the proportion of female mites with intrauterine eggs) is perhaps stimulated by immunosuppression via the sex hormones in pregnant and lactating bat females (Grossman, 1985), and by the energetically restricted low female grooming activity (Kurta et al., 1989, 1990, Encarnação et al., 2012), leading to the sex differences in infestation. Male bats usually locate separately from the breeding colony, are not involved in nursing, and are able to engage in unhindered grooming behaviour without the immunosupression caused by pregnancy. This can explain why the mite load in male bats is lower than in females throughout the seasonal activity period. 
Thus, peak infestation occurs up to the period when the young bats begin to fly, after which the infestation drops dramatically mainly due to the improved grooming of flying juveniles and the intensified grooming of females. The reduced infestation is possibly also enhanced by frequent roost switching during the disbanding of the summer colony. Roost switching as a antiparasitic strategy against nycteribiid flies (ectoparasites with prolonged feeding as in Steatonyssus) is described, for example, in Myotis bechsteini Kuhl, 1817 (Reckardt \& Kerth, 2009), but this aspect has been poorly studied).

Our study highlights the complex interacting effects of sex, age and grooming behaviour on the dynamics of mite infestation in parti-coloured bat colonies. We consider that gender-biased infestations by mites are closely related to the physiological and behavioural processes associated with reproduction. This idea should be further investigated with similar studies on the hostparasite relationship of $V$. murinus and gamasid mites during the hibernation period.

ACKNOWLEDGEMENTS. We thank the heads of the State Nature Biosphere Reserve Daursky for their valuable contributions during the fieldwork. This study was supported by the project 'Biotic components of ecosystems, their properties, resource potential, and dynamics under the conditions of transformation of the natural environment of Western Siberia' (state contract no. $6.567 .2014 / \mathrm{k}$ ) and the project for raising the competitiveness of the leading Russian universities among the world's research and education centres (Project 5100).

\section{References}

Balashov Y.S. 2009. [Parasitism of ticks and insects on vertebrates]. Saint-Petersburg: Nauka. 358 p. [in Russian].

Baley J.E. \& Schacter B.Z. 1985. Mechanisms of diminished natural killer cell activity in pregnant women and neonates // Journal of Immunology. Vol.134. P.3042-3048.

Benda P.\& Horáček I. 1998. Bats (Mammalia: Chiroptera) of the Eastern Mediterranean. Part 1. Review of distribution and taxonomy of bats in Turkey // Acta Societatis Zoologicae Bohemicae. Vol.62. P.255-313.

Benda P., Faizolahi K., Andreas M., Obuch J., Reiter A., Ševčík M., Uhrin M., Vallo P.\& Ashraf S. 2012. Bats (Mammalia: Chiroptera) of the Eastern Mediterranean and Middle East. Part 10. Bat fauna of Iran // Acta Societatis Zoologicae Bohemicae. Vol.76. P.163-582.

Borisenko A.V. 1999. [Mobil trap for bat catching] // Plecotus et al. Vol.2. P.10-19 [in Russian with English summary].

Booth D.T., Clayton D.H. \& Block B.A. 1993. Experimental demonstration of the energetic cost of parasitism in freeranging hosts // Proceedings of the Royal Society of London. Biological Sciences. Vol.253. P.125-129.

Christe P., Arlettaz R. \& Vogel P.2000. Variation in intensity of a parasitic mite (Spinturnix myoti) in relation to the reproductive cycle and immunocompetence of its bat host (Myotis myotis) // Ecology Letters. Vol.3. P.207212.

Christe P., Giorgi M.S., Vogel P. \& Arlettaz R. 2003. Differential species-specific ectoparasitic mite intensities in two intimately coexisting sibling bat species: resourcemediated host attractiveness or parasite specialisation? // Journal of Animal Ecology. Vol.72. P.866-872.

Christe P., Glaizot O., Evanno G., Bruyndonckx N., Devevey G., Yannic G., Patthey P., Maeder A., Vogel P. \& Arlettaz R. 2007. Host sex and ectoparasites choice: preference for and higher survival on female hosts // Journal of Animal Ecology. Vol.76. P.703-710.

Clayton D.H. 1991. Coevolution of avian grooming and ectoparasite avoidance // Loye J.E. \& Zuk M. (eds.). Bird-parasite interactions, ecology, evolution and behavior. New York: Oxford University Press. P.258-289.

Dick C.W. \& Patterson B.D. 2006. Bat flies: obligate ectoparasites of bats // Morand S., Krasnov B. \& Poulin R. (eds.). Micromammals and Macroparasites: From Evolutionary Ecology to Management. Tokyo: Springer-Verlag Publishing. P.179-194.

Dusbabek F. 1972. The zone of bat acarinia in Central Europe // Folia parasitologica. Vol.19. P.139-154.

Encarnação J.A., Baulechner D. \& Becker N.I. 2012. Seasonal Variations of Wing Mite Infestations in Male Daubenton'S Bats (Myotis daubentonii) in Comparison to Female and Juvenile Bats // Acta Chiropterologica. Vol.14. No.1. P.153-159.

Faraway J.J. 2006. Extending the linear model with R: Generalized linear, mixed effects and nonparametric regression models. Boca Raton-London-New York: Chapman \& Hall/CRC. P.331.

Furukawa K., Itoh K., Okamura K., Kumagai K. \& Suzuki M. 1984. Changes in NK cell activity during the estrous cycle and pregnancy in mice // Journal of Reproductive Immunology. No.6. P.353-363.

Giorgi M.S., Arlettaz R., Christe P. \& Vogel P. 2001. The energetic grooming costs imposed by a parasitic mite (Spinturnix myoti) upon its bat host (Myotis myotis) // Proceedings of the Royal Society of London. Biological Sciences. Vol.268. P.2071-2075.

Grossman C.J. 1985. Interactions between the gonadalsteroids and the immune system // Science. Vol.227. P.257-261.

Haitlinger R. 1978. Pasozyty zewnetrzne nietoperzy Dolnego Śląska. III. Spinturnicidae, Argasidae, Ixodidae (Acarina) // Wiadomosci parazitologiezne. Vol.24. P.475-490.

Hart B.L. 1997. Behavioural defence // Clayton D.H. \& Moore J. (eds.) Host-parasite evolution. General principles and avian models. NewYork: Oxford University Press. P.59-77.

Hosken D.J. \& O'Shea J.E. 2001. Sperm production and immune function in two Australian bats, Chalinolobus morio and Nyctophilus geoffroyi // Ethology Ecology \& Evolution. Vol.13. P.173-180.

Khabilov T.K. 1992. [Mammals. Bats]. Dushanbe: Donish, 351 p. [In Russian, with English summary].

Klein S.L. 2000. The effects of hormones on sex differences in infection: from genes to behavior // Neuroscience \& Biobehavioral Reviews. Vol.24. P.627-638. 
Klein S.L. 2004. Hormonal and immunological mechanisms mediating sex differences in parasite infection. Parasite Immunology. Vol.26. No.6-7. P.247-264.

Kurta A., Bell G.P., Nagy K.A. \& Kunz T.H. 1989. Energetics of pregnancy and lactation in free-ranging little brown bats (Myotis lucifugus) // Physiological Zoology. Vol.62. P.804-818.

Kurta A., Kunz T.H. \& Nagy K.A. 1990. Energetics and water flux of free-ranging big brown bats (Eptesicus fuscus) during pregnancy and lactation // Journal of Mammalogy. Vol.71. P.59-65.

Lourenço S. \& Palmeirim J.M. 2008. Which factors regulate the reproduction of ectoparasites of temperate-zone cavedwelling bats? // Parasitology Research. Vol.104. No.1. P.127-134.

Lučan R.K. 2006. Relationships between the parasitic mite Spinturnix andegavinus (Acari: Spinturnicidae) and its bat host, Myotis daubentonii (Chiroptera: Vespertilionidae): seasonal, sex- and age-related variation in infestation and possible impact of the parasite on the host condition and roosting behaviour // Folia Parasitologica. Vol.53. P.147-152.

Mastitskiy S.E. \& Shitikov V.K. 2015. [Statistical analysis and data visualisation using R]. Moscow: DMK-Press. 496 p. [in Russian].

McKay L.I. \& Cidlowski J.A. 1999. Molecular control of immune/inflammatory responses: interactions between nuclear factor kappa B and steroid receptor-signaling pathways // Endocrine Reviews. Vol.20. P.435-459.

McLean J.A. \& Speakman J.R. 1997. Non-nutritional maternal support in the brown long-eared bat // Animal Behaviour. Vol.54. P.1193-1204.

Marshall A.G. 1981. The ecology of ectoparasitic insects. London: Academic Press. 459 p.

Miller L. \& Hunt J.S. 1996. Sex steroid hormones and macrophage function // Life Sciences. Vol.59. P.1-14.

Micherdzinski W. 1980. Eine Taxonomische Analyse der Familie Macronyssidae Oudemans, 1936. I: Subfamilie Ornithonyssinae Lange, 1958 (Acarina: Mesostigmata). Warszawa: Polska Akademia Nauk. 254 p.

Møller A.P., De Lope F., Moreno J., Gonzales G. \& Perez J.J. 1994. Ectoparasites and host energetics: house martin bugs and house martin nestlings // Oecologia. Vol.98. P.263-268.

Mooring M.S. \& Hart B.L. 1995. Differential grooming rate and tick load of territorial-male and female impala, Aepyceros melampus // Behavioural Ecology. Vol.6. P.94-101.

Morales-Montor J., Mohamed F. \& Damian R.T. 2004. Schistosoma mansoni: the effect of adrenalectomy on the murine model // Microbes and Infection. Vol.6. No.5. P. 475-480.

Ogajanyan A.M. \& Arutyunyan E.S. 1974. [Mites of fam. Macronyssidae Oudemans, 1936 (Parasitiformes, Gamasoidea) parasitizing bats of Armenia] // Biological Journal of Armenia. Vol.27. No.10. P.75-82. [In Russian with Armenian summary].

Orlova M.V., Orlov O.L. \& Kshnyasev I.A. 2012. Changes in the abundance of parasitic gamasid mite Macronyssus corethroproctus (Oudemans, 1902) during the overwintering period of its host, the Pond bat Myotis dasycneme
(Boie, 1825) // Russian Journal of Ecology. Vol.43. No.4. P.328-332.

Orlova M.V. 2013. Ectoparasites of the parti-coloured bat (Vespertilio murinus Linnaeus, 1758, Chiroptera, Mammalia) in the Urals and adjacent regions // Entomological Review. Vol.93. No.9. P.1236-1242.

Orlova M.V., Kshnyasev I.A., Orlov O.L. \& Zhigalin A.V. 2015a. Some factors behind density dynamics of bat flies (Diptera, Nycteribiidae) - ectoparasites of the boreal chiropterans: omitted predictors and hurdle model identification // Vestnik zoologii. Vol.49. No.4. P.333-340.

Orlova M., Orlov O., Zhigalin A. \& Mishchenko V. 2015b. Comparative analysis of vespertilionid bats' (Chiroptera: Vespertilionidae) infestation with gamasid mites of the genus Macronyssus Kolenati, 1858 during hibernation in the Urals and Western Siberia // Zoology and Ecology. Vol.25. No.4. P.314-318.

Orlova M.V., Stanyukovich M.K. \& Orlov O.L. 2016. Gamasid mites (Mesostigmata: Gamasina) parasitizing bats (Chiroptera: Rhinolophidae, Vespertilionidae, Molossidae) of Palaearctic boreal zone (Russia and adjacent countries). Tomsk: TSU Publishing House. 150 p.

Pinchuk L.M. 1971. [Mites of the genus Steatonyssus (Parasitiformes: Macronyssidae) from bats of Moldova] // Animal and plant parasites. Kishinev. Vol.7. P.110-115 [in Russian].

Racey P.A. 2009. Reproductive assessment of bats // Kunz T.H. \& Parsons S. (eds.) Ecological and behavioural methods for the study of bats. Baltimore: Johns Hopkins University Press. P.249-264.

Reckardt K. \& Kerth G. 2009. Does the mode of transmission between hosts affect the host choice strategies of parasites? Implications from a field study on bat fly and wing mite infestation of Bechstein's bats // Oikos. Vol.118. P.183-190.

Roulin A., Brinkhof M.W.G., Bize P., Richner H., Jungi T.W., Bavoux C., Boileau N. \& Burneleau G. 2003. Which chick is tasty to parasites? The importance of host immunology vs. parasite life history // Journal of Animal Ecology. Vol.72. P.75-81.

Rupp D., Zahn A. \& Ludwig P.2004. Actual records of bat ectoparasites in Bavaria (Germany) // Spixiana. Vol.27. No.2. P.185-190.

R Development Core Team. 2011. R: A language and environment for statistical computing. Vienna, Austria: R Foundation for Statistical Computing. Available from: http://www.R-project.org

Rybin S.N. 1983. [Gamasid mites of bats and their shelters in South Kyrgyzstan] // Parasitologiya. Vol.17. No.5. P.355360 [in Russian with English summary].

Rydell J. \& Baagøe H.J. 1994. Vespertilio murinus // Mammalian Species. Vol.467. P.1-6.

Savita X.X., Rai U. 1998. Sex steroid hormones modulate the activation of murine peritoneal macrophages: receptor mediated modulation // Comparative Biochemistry and Physiology. Part C: Pharmacology, Toxicology and Endocrinology. Vol.119. P.199-204.

Sharifi M., Mozafari F., Taghinezhad N. \& Javanbakht H. 2008. Variation in ectoparasite load reflects life history traits in the lesser mouse-eared bat Myotis blythii (Chi- 
roptera: Vespertilionidae) in western Iran // Journal of Parasitology. Vol.94. No.3. P.622-625.

Shitikov V.K., Rosenberg G.S. 2014. [Randomization and bootstrap: a statistical analysis in biology and ecology using R]. Togliatti: Cassandra. 314 p. [In Russian with English summary].

Stanyukovich M.K. 1990. [Gamasid mites and argasid ticks of bats from Pribaltica and Leningrad district] // Parasitologiya. Vol.24. No.3. P.193-199 [in Russian with English summary].

Stanyukovich M.K. 1993. [Gamasid mites of bats from Russia and adjunct countries (Gamasina: Spinturnicidae, Macronyssidae)]: thes. diss.... PhD. St. Petersburg. 16 p. [In Russian].

Stanyukovich M.K. 1997. Keys to the gamasid mites (Acari: Parasitiformes, Mesostigmata, Macronyssoidea et Laelaptoidea) parasiting bats (Mammalia, Chiroptera) from Russia and adjacent countries // Rudolstädter naturhistorische Schriften. Vol.7. P.13-46.

Sundary A.A., Bogdanowicz W., Varman D.R., Marimuthu G. \& Rajan K.E. 2012. Ectoparasite Raymondia lobulata infestation in relation to the reproductive cycle of its host - the greater false vampire bat Megaderma lyra // Journal of Parasitology. Vol.98. P.60-62.

Teng K.F. 1980. Notes on the genus Steatonyssus in China (Acarina: Macronyssidae) // Acta Zootaxonomica Sinica. Vol.5. No.1. P.59-62.
Till W.M. \& Evans G.O. 1964.The genus Steatonyssus Kolenati (Acari: Mesostigmata) // Bulletin of the British Museum (Natural History). Vol.11. P.511-582.

Toder V., Nebel L., Elrad H., Blank M., Durdana A. \& Gleicher N. 1984. Studies of natural killer cells in pregnancy. II. The immunoregulatory effect of pregnancy substances // Journal of Clinical Immunology. Vol.14. P.129-133.

Vasen'kov D. A. \& Potapov M. A. 2007. [Using body condition index in a study of bat ecology] // Plecotus et al. Vol.10. P.21-31 [in Russian with English summary].

Wikel S.K. 1996. The immunology of host-ectoparasitic arthropod relationships. Wallingford: CAB International. $331 \mathrm{p}$.

Whitaker J.O., Jr. 1988. Collecting and preserving ectoparasites for ecological study // Kunz T.H. (ed.) Ecological and Behavioral Methods for the Study of Bats. Washington: Smithsonian Inst. Press. P.459-474.

Zahn A. \& Rupp D. 2004. Ectoparasite load in European vespertilionid bats // Journal of Zoology. London. Vol.262. No.4. P.1-9.

Zhang L., Parsons S., Daszak P., Wei L., Zhu G. \& Zhang S. 2010. Variation in the abundance of ectoparasitic mites of flat-headed bats // Journal of Mammalogy. Vol.91. No.1. P.136-143.

Zemskaya A.A. 1973. [Parasitic gamasid mites and their medical importance]. Moscow: Meditsina. 167 p. [In Russian]. 